\title{
What determines the innovation capability of firm founders?
}

\author{
Spyros Arvanitis ${ }^{*, \dagger}$ and Tobias Stucki**
}

Innovative start-ups, not start-ups in general, seem to be important drivers of economic growth. However, little is known about what such firms look like. As activities of start-ups are strongly related to firm founders, we investigate this question focusing on the innovation capability of firm founders. We find that the combination of different founder characteristics such as university education (at best a combination of technical and commercial education), prior experience in $R \& D$, and strong motivation to realize own innovative ideas increases the likelihood that a start-up has innovative activities, especially the likelihood of R\&D activities, by $>40 \%$.

JEL classification: M13, L26, O30.

\section{Introduction}

Most start-ups have more in common with self-employment than with the creation of high-growth companies (Shane, 2009: 142). Along with Shane (2009), several recent papers thus conclude that simply encouraging more people to become entrepreneurs is not necessarily the best policy for enhancing economic growth (see, e.g. Fritsch and Schroeter, 2009; Bosma et al., 2011; Cantner and Kösters, 2011). Hence, especially for policy makers, it is important to be able to identify firms with a high probability of growth perspectives. Starting point of our analysis is the idea that an important characteristic of such high-growth firms is their innovation performance. Innovative start-ups are considered to be important drivers of innovation in existing industries (Schumpeter, 1934; Aghion et al., 2009) and should also positively

\footnotetext{
${ }^{*}$ Spyros Arvanitis, ETH Zurich, KOF Swiss Economic Institute, CH-8092 Zurich, Germany. e-mail: arvanitis@kof.ethz.ch

${ }^{* *}$ Tobias Stucki, ETH Zurich, KOF Swiss Economic Institute, CH-8092 Zurich, Germany. e-mail: stucki@kof.ethz.ch

${ }^{\dagger}$ Main author for correspondence.
} 
affect the creation of new industries (Acs and Audretsch, 1990). Despite this expected positive impact on economic growth, relatively little is known about the factors that determine the innovation performance of start-ups.

The innovative activity of start-ups might strongly depend on the characteristics of the firm founders, e.g. educational background and experience. The founders determine a firm's strategies and coordinate the resources to implement them (Bergmann Lichtenstein and Brush, 2001; Barringer et al., 2004). Further, as start-ups are mostly small firms, the capabilities of the founders themselves serve as important resources to create a competitive advantage (Hadjimanolis, 2000). Founders do not only decide whether to innovate or not, but are directly involved in the innovation process of the start-ups. Knowing the innovation capability of firm founders would make it much easier to identify the innovative start-ups, especially as most of these characteristics are easy to observe and remain constant over time.

While there is empirical evidence for such a link between management characteristics and innovation activities for established firms (see, e.g. Hadjimanolis, 2000; Barker and Mueller, 2002; Romijn and Albaladejo, 2002; Chen et al., 2010), to our knowledge only two studies deal with the relationship between founder characteristics and innovation using data of newly founded firms. The first one is the study of Lynskey (2004) that analyze the impact of the CEO characteristics based on Japanese firm-level data that were collected in 1999 and refer to technology-based firms that were founded 10 years or less before the survey, i.e. at the earliest in 1989. In a second study, Koch and Strotmann (2008) analyze the impact of founder characteristics on the innovation performance of German start-ups in the knowledge-intensive business sector. In both studies, managerial characteristics and founder characteristics, respectively, showed rather low explanatory power.

Our study contributes several new elements to existing empirical literature. Our empirical basis is a sample of start-ups that is representative of all firms founded in $1996 / 1997$ in Switzerland as recorded by a census of the Swiss Federal Statistical Office for this period. Further, while previous studies are based on data for one cross section, we dispose of data for three cross sections, so that we can follow the development of the start-ups over a period of almost 10 years. This allows us to analyze at the same time the existence and the persistence of innovation activities. Furthermore, we can also investigate the effects of changes of the composition of the founding teams on innovation. Another important feature of our study is the wide spectrum of variables, especially with respect to founder characteristics, that could be taken into account in the model specification. In previous studies, the available founder information is limited and not really representative for the whole founding team.

As already mentioned in this article, we investigate the influence of founder characteristics on the innovative activity of start-ups based on Swiss data for the start-up cohort 1996/1997. We find that the founders' education level, the level of their experience in $R \& D$ and the availability of innovation-relevant ideas coming from the founder persons are the main characteristics that enhance innovation activities of 
start-ups. We also find mutually reinforcing effects of these most important founder characteristics. At the maximum, combinations of these three factors within a founding team can increase the probability of innovative activities by $\sim 40 \%$.

The remainder of the article is organized as follows: Section 2 presents the conceptual background of the empirical analysis and derives our main hypotheses. Section 3 describes the database. Section 4 discusses the methodology of our analysis. Section 5 presents the estimation results and a comparison with results of similar studies. Section 6 concludes our article.

\section{Conceptual background and hypotheses}

Our conceptual framework builds upon the resource-based approach of the firm, according to which a direct link is assumed between a firm's competitive advantage and the individual resources of the employees, especially with respect to managing persons (see Barney, 1991). Thus, the performance of start-ups should be strongly related to their innovation capability as reflected by the individual resources and capabilities of the founding persons (see, e.g. Hadjimanolis, 2000; Romijn and Albaladejo, 2002; Capaldo et al., 2003 for a similar approach). As most start-ups are small firms, firm founders are directly involved in the operational process of the firms. Founders also make strategic decisions such as the choice to innovate or not. Knowledge and skills of entrepreneurs are thus important resources of the start-ups and should also impact innovative activity. In this article, we analyze the relationship between innovative activity of start-ups and founder characteristics, embedded in an extensive model of determinants of innovation.

In view of the complexity of the innovation process characterized by several stages from basic research to the penetration of the market with new products, an approach relying on a single measure of innovation may leave out important relationships and produce results that are not robust (see, e.g. Rogers, 1998; Kleinknecht et al., 2002). In this study, we use two innovation measures covering the input as well as the output side of the innovation process. In our model, innovation output is measured by the introduction of new or modified products (IP). The existence of R\&D activities (R\&D) indicates innovation input. Following the theoretical literature and in accordance with empirical studies, our model includes three categories of independent variables: founder characteristics, firm characteristics, and characteristics of a firm's environment.

\subsection{Founder characteristics}

As we primarily focus on the impact of the founder characteristics on the innovative activity, we include an extensive set of variables which may be related to the innovation capability of the firm founders. Firms in our sample may be founded by a group of founders or by a single founder. Variables describing the characteristic of 
the firm founders thus refer to the characteristics of the whole founding team, independent of whether the firm was founded by a team with more than one founder or by a single founder.

Theoretical literature on entrepreneurship either deals with single entrepreneurs (see Lazear, 2005) or with team foundations (see Fabel, 2004). Empirically, however, there may be significant differences between solo and team start-ups. Team foundations combine people with diverse personalities, characteristics, knowledge, skills, and abilities. Such combinations could positively stimulate the performance of the firms (see Thakur, 1999; Lechler, 2001). Furthermore, the number of external network relationships and the availability of resources should be positively correlated with team foundations (see Brüderl et al., 2007), also indicating a positive impact on innovative activities. On the other hand, heterogeneity increases the risk of problems and conflicts within the founding team (see Stam and Schutjens, 2006; Brüderl et al., 2007). In line with the findings of most previous empirical studies on the economic performance of start-ups, we expect, however, that the positive effects of team foundations outweigh the negative ones. Hence, our first hypothesis is as follows:

H1: Innovation propensity should be higher in firms with team foundations than in firms with single founders.

The human capital of the founding team, especially the education level of the founders, should be an important factor for innovation. Through formal education people acquire skills that help to recognize business opportunities in the surrounding environment (Shane, 2000). Further, a higher level of education may increase the ability to absorb new ideas, thus the ability to identify innovative opportunities (Barker and Mueller, 2002: 787). This is the rationale of the competence-based view according to which founders with great human capital would outperform founders with less human capital (see Colombo and Grilli, 2005 for a more detailed development of this argument). Furthermore, it is more likely that founders with a high education would dispose of more wealth than persons without a high education. Thus, they would also have access to more capital to finance firm's operations. In this case, economic access may be traced back primarily to better internal and external financing opportunities (wealth-based view; see, e.g. Åstebro and Bernhardt, 2005) and the wealth effect would explain the positive effect of human capital (see Colombo and Grilli, 2005). In this study, we correlate human capital directly with innovation, so we have the possibility to test the competence-based view. Accordingly, we formulate hypothesis as follows:

H2: We expect that firms with a founding team with a high level of formal education would show a higher propensity to innovation than firms with a founding team with a lower level of education.

Not only the level of formal education, but also the type of education of the founders may impact innovation. Commercial education primarily enhances 
accounting and marketing capabilities. In contrast, people with a technical education background may have a more complete understanding of technology and innovation (Hambrick and Mason, 1984: 201; Barker and Mueller, 2002: 787).

H3: These arguments suggest that firms with founding teams with pronounced technical know-how would tend to have more innovative activities than firms with founding teams with primarily commercial education.

Implementation of an innovation strategy is made under conditions of uncertainty. Experiences of a founding team in dealing with such situations are presumed to decrease the actual risk being faced (see McGee et al., 1995; Marino and De Noble, 1997; Carpenter et al., 2003). Accordingly, innovation-relevant experiences should increase the probability of innovation activities within the firm. To capture the effect of innovation-relevant experience, we include variables that measure four different types of founder experience: industry experience, self-employment experience, R\&D experience, and concrete innovation-relevant ideas from a founder's former occupation.

Prior industry experience affects considerably the ability to detect (innovative) opportunities and to react to changing business conditions (Marino and De Noble, 1997; Shane, 2000; Nerkar and Shane, 2003; Colombo and Grill, 2005; van Gelderen et al., 2006). As new firms have no track record, such experience is of special importance. In order to be able to identify opportunities for new products and services, it is important for a firm founder to be familiar with customer needs and market developments.

H4: We thus expect that founding teams with prior industry experience would tend to initiate more innovative activities than founding teams without or little prior industry experience.

Previous self-employment experience indicates the accumulation of business skills. Experience gained in previous self-employment episodes is a preparation for the entrepreneurial role (Brüderl et al., 1992: 229; see also Marino and De Noble, 1997; Colombo and Grilli, 2005; van Gelderen et al., 2006). Starting a new business requires specific management know-how, for example with respect to finances or organization of production or marketing. Prior experience as self-employed reduces costs to manage "basic" tasks, thus allowing firm founders to concentrate on other tasks such as innovation activities.

H5: We expect that founding teams with self-employment experience have more innovative activities than founding teams without self-employment experience.

Even if formal education and previous industry and management experience are often necessary preconditions they may not be sufficient for innovation. "The idiosyncratic, noncontractible nature of entrepreneurial judgment when an individual identifies a new and hitherto unrecognized business opportunity" as Colombo and 
Grilli (2005: 80) put it, is presumably a crucial characteristic of innovative founders (see also Foss, 1993). To capture such effects, our next two hypotheses deal with more innovation specific experience of the founding teams.

Innovative activities imply a certain level of innovation-specific know-how. This type of knowledge is needed to assess the potential of competing research streams, to develop ReD strategies or to organize and coordinate research projects (see McGee et al., 1995; Barker and Mueller, 2002; Lynskey, 2004). Thus, a further hypothesis is as follows:

H6: Founding teams with R\&D experience have more innovative activities than founding teams without such experience.

Besides specific innovation know-how in technical terms, innovative activities often build upon concrete ideas about possible innovative projects based on experience made in earlier occupations of the founders either in research or in business. The realization of such innovation-relevant ideas is often an important motivation for starting a new business. The decision whether a firm has innovative activities should thus also depend on the availability of such innovation-relevant ideas. As a consequence, our last hypothesis is as follows:

H7: In firms which were founded to implement concrete ideas from a founder's former occupation, innovation-relevant ideas seem to be available. Therefore, we would expect that these firms have more innovation activities.

Investment in innovation is a long-term investment and pay-offs are uncertain at the time of investment. Innovative activities would thus be related to the risk behavior of the founding team. An important proxy for this behavior is the age of firm founders. As older firm founders have a shorter investment horizon and are more inclined to secure primarily their retirement income, they would tend to be more risk-averse than younger founders (see Hambrick and Mason, 1984: 198). Risk-taking is also influenced by gender. Women typically are more likely to be risk-averse (see, e.g. Jianakoplos and Bernasek, 1998; Eckel and Grossman, 2002). So, we include in our model specification also controls for the average age as well as for the gender of the majority of the founding team.

\subsection{Firm characteristics}

As most start-ups are small firms, it is difficult to separate the effect of the founding team and the effect of the other employees of the start-ups. Thus, we refrain from including in addition to the variables describing the founder characteristics also variables measuring the human resources of the other employees. We control for such resources by inserting a variable for firm size. Larger firms are expected to have more resources for innovation projects than smaller ones. Firm size would thus positively impact innovation activities. 
Competing on the international market requires competitive advantages. The export orientation of a firm would thus be positively correlated with its innovative activity (see Roper and Love, 2002). Since diversified firms have more opportunities to use new knowledge, product diversification would enhance innovative activities of these firms (see Katila, 2002: 1002). ${ }^{1}$

\subsection{Market conditions}

We expect that positive demand expectations would positively stimulate present innovation activities (see Horbach, 2008).

Internal resources of start-ups are limited. External networks can provide additional knowledge and expertise (Malerba and Torrisi, 1992; Shan et al., 1994). Cooperation with other firms or institutes, especially cooperation in $R \& D$, would increase the amount of available knowledge and thus positively impact innovative activities. Furthermore, as start-ups are often financially constrained, innovation activities may be stimulated by public financial support. In our sample, however, $<5 \%$ of the firms received public subsidies and for only $1 \%$ of the firms this financial support was of high importance. So, we refrain from inserting a variable for public support in our model.

Markets with intensive competition require greater flexibility and would in general force firms to become more innovative (Katila and Shane, 2005). However, as experience and resources of start-ups in general are limited, intensive price competition may discourage innovation, intensive nonprice competition encourage it. Finally, to capture industry specific effects, we further include dummies controlling for sector affiliation. To capture different effects for modern services and traditional services, respectively, we include a separate dummy for each of the two subsectors. ${ }^{2}$

\section{Description of the data}

The sample used in this study is based on the cohort of Swiss enterprises that were founded between 1996 and 1997 and recorded by the Swiss Federal Statistical Office. This cohort contained 7112 "green-field" start-ups (i.e. mergers and manager-takeovers were not included) that were founded in this period and were active (i.e. conducted business activities at least $20 \mathrm{~h}$ a week). ${ }^{3}$ For this sample, only

\footnotetext{
${ }^{1}$ Diversification would make it more difficult for the management to monitor the firm's R\&D activities. In large firms, this may lead to decreasing commitment to innovation activities, but this is of limited relevance for the small start-ups in our sample.

${ }^{2}$ As $<10 \%$ of the firms in our sample belong to the manufacturing sector, it was not possible to make such a distinction for the manufacturing sector.

${ }^{3}$ The firms were recorded by the Swiss Federal Statistical Office independently whether they were enrolled in the Swiss Commercial Register or not.
} 
the firm size, the industry affiliation, and the region of the firms' location were known. Of these, 3288 start-ups were still in business in 2000 (survival rate 2000: 46.2\%). ${ }^{4}$ Among these firms, data were collected by means of a postal survey. Among them, 1625 firms answered the questionnaire (response rate 2000: 49.2\%). Of these, 1339 firms survived the next 3 years (survival rate 2003: 82.4\%). In 2003, a follow-up survey was conducted among the surviving firms. Answers were received from 945 of the firms (response rate 2003: 70.6\%). In 2006, 3 years after the second survey and 910 years after the firm's foundation, 857 of the participants of the 2003 survey still existed (survival rate 2006: 90.7\%). Of them, 630 were willing to fill out a third questionnaire (response rate 2006: 73.6\%). For some firms, we thus have data at different points in time. For firms which dropped out of the sample we know whether the firm still existed at the time of dropout and also whether the firm survived the following period up to 2006. In sum, the data set covers 3200 observations. Because of missing values for single variables only 2393 observations could be used for econometric estimations.

Most of the start-ups in the data set are firms in the service sector. In each point of time, they represent $\sim 83 \%$ of the observations. About $9 \%$ belong to the construction sector, the remaining $8 \%$ to the manufacturing sector. These shares remained almost constant during the period 2000-2006. In the service sector, the subsector of modern (knowledge-intensive) services (e.g. banking and insurance, business services) has a larger share than the subsector of traditional services (e.g. trade, hotels, and catering); the share of modern services increased considerably between 2000 and 2006 (coming to $\sim 47 \%$ in 2006$)$. In the manufacturing sector, there are more low-tech $(\sim 5 \%)$ than high-tech start-ups $(\sim 3 \%)$.

The observed start-ups are for the most part small firms. In each survey, $>80 \%$ of the enterprises employed less than five employees (measured in full-time equivalents). The average firm size only slightly increased from one period to the next. While in 2000 the firms had on average a size of 2.8 employees, the average size increased to 3.6 employees in 2003 and 5.3 employees in 2006. In 2006, 10 years since their foundation, only $8.4 \%$ of the firms employed more than 10 employees.

The questionnaire covered questions about basic firm characteristics, firm performance, and activity level, resource endowment, innovative activities, and the market environment. ${ }^{5}$ In 2000, the questionnaire included detailed questions about the founder characteristics (e.g. gender, age, education, experience) at time of firm foundation. As we have this information for up to three representative firm

\footnotetext{
${ }^{4}$ The current status of the firms was checked to a large part by phone.

${ }^{5}$ The questionnaire is available in German, French and Italian at www.kof.ethz.ch/surveys/struc tural/panel.
} 
founders and $<4 \%$ of the firms in our sample have more than three founders, we are able to describe in detail the characteristics of the entire founding team.

\section{Econometric framework}

To capture different aspects of innovative activity we estimate our model using a proxy for innovation input as well as a proxy for innovation output. R\&D is a binary variable measuring whether a firm had $\mathrm{R} \& \mathrm{D}$ activities. IP is also a binary variable measuring whether a firm introduced new or modified products.

To explain innovative activities we include all variables presented in Section 2 (for a detailed definition of the variables and descriptive statistics by cross section see Table 1 and Table A1 in Appendix A, respectively). Models comprise for both innovation variables the same independent variables. To take into account the binary character of the dependent variables, we estimate probit models.

\subsection{Sample attrition}

Between two subsequent surveys some firms disappeared from the market and some other did not want to participate to our survey anymore. The question is whether the remaining samples are still representative. When determinants of selection are correlated with innovative activities, attrition is selective, and traditional econometrical techniques will lead to biased and inconsistent estimates. Following Wooldridge (2002: 581), we test for selective attrition between two cross sections by inserting a selection indicator as an additional explanatory variable in our model, running the regression and testing the statistical significance of the coefficient of the selection indicator. As a selection indicator, we use the dummy variable INSAMPLE that takes the value one if a firm is still in our sample in the following cross section and zero if not. We have no such indicator for cross section 2006, so we can apply this test only for the cross sections 2000 and 2003.

Test results indicate that selective attrition is of minor importance; the coefficient of the selection variable is only in one of eight models statistically significant (at the 5\% test-level) (see Table A2 in Appendix A). This result is further supported by cross section-specific descriptive statistics for the founder characteristic variables. Descriptive statistics for these time-invariant variables show that the composition of the data set does not significantly vary between cross sections (Table A1 in Appendix A). Thus, pooling the data of the different cross sections without correcting for selective attrition seems to be an adequate procedure.

\subsection{Heterogeneity}

Likelihood-ratio tests show that the pooled probit model is not the appropriate estimation method (see the lower part of Table 2). Fixed-effects approaches 
Table 1 Definition and measurement of model variables

Variable

Dependent variables
R\&D
IP
Independent variables
LEVEL_UNI, LEVEL_O_TERTIARY

TYPE TECHNICAL, TYPE_COMMERCIAL, TYPE_MIX

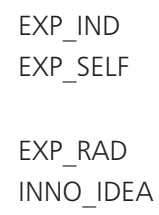

LAGE

GENDER

MALE_TEAM, MIXED_TEAM
Definition/measurement

R\&D activities yes/no

Development and introduction of new/modified existing products yes/no

Dummies describing the dominant education level of the firm founders (most founders have a university degree (LEVEL_UNI); most founders have another tertiary-level education (LEVEL_O_TERTIARY); reference group: most founders do not have a tertiary-level education)

Dummies describing the type of strength of the founding team [team has pronounced technical but not management know-how (TYPE_TECHNICAL); team has pronounced management but not technical know-how (TYPE_COMMERCIAL); team has pronounced technical as well as management know-how (TYPE_MIX); reference group: team has not pronounced technical and management know-how; transformation of two five-level ordinal variables (level 1: "very weak;" level 5: "very strong") to binary variables (value 1: levels 4 and 5 of the original five-level variable; value 0 : levels 1,2 , and 3 of the original variable)]

At least one of the founders has industry experience yes/no At least one of the founders has experience with self employment yes/no

At least one of the founders has R\&D experience yes/no

Firm was founded to implement concrete ideas from the founders former occupation yes/no [transformation of a five-level ordinal variable (level 1: "very low importance;" level 5: "very high importance") to a binary variable (value 1 : levels 4 and 5 of the original five-level variable; value 0 : levels 1, 2, and 3 of the original variable)]

Average age of the firm founders; natural logarithm

Gender of the firm founders: male/female (value 1: "male;" value 0: "female;" the most frequently reported gender is regarded as representative for the firm founders; when the number of "females" equals the number of "males" we set "female")

Dummies describing the gender mix of the founding team (all team members are male (MALE_TEAM); there are 
Table 1 Continued

\begin{tabular}{|c|c|}
\hline Variable & Definition/measurement \\
\hline & $\begin{array}{l}\text { males and females in the founding team (MIXED_TEAM); } \\
\text { reference group: all team members are female) }\end{array}$ \\
\hline TEAM_FOUNDATION & Firm was founded by at least two founders yes/no \\
\hline LSIZE & Number of employees; natural logarithm \\
\hline EXPORT & Firm exports goods and/or services yes/no \\
\hline DIVERSIFICATION & $\begin{array}{l}\text { Firm is present in more than one product and/or service } \\
\text { sector yes/no }\end{array}$ \\
\hline DEMAND_FUTURE & $\begin{array}{l}\text { Development of a firm's specific product demand in the next } \\
\text { two years [transformation of a five-level ordinal variable } \\
\text { (level 1: "strong decrease;" } 5 \text {; "strong increase") referring } \\
\text { to the (reference year: survey year); to a binary variable } \\
\text { (value 1: levels } 4 \text { and } 5 \text {; value } 0 \text { : levels } 1,2 \text {, and } 3 \text { of the } \\
\text { original five-level variable)] }\end{array}$ \\
\hline COOPERATION & $\begin{array}{l}\text { Firm cooperates with other firms/institutes yes/no (dummy } \\
\text { variable measures whether or not a firm cooperates in } \\
\text { acquisition, production, distribution or R\&D) }\end{array}$ \\
\hline PCOMP & $\begin{array}{l}\text { Intensity of price competition (transformation of a five-level } \\
\text { ordinal variable [level 1: "very weak;" level } 5 \text { : "very } \\
\text { strong") to a binary variable (value } 1 \text { : levels } 4 \text { and } 5 \text { of } \\
\text { the original five-level variable; value } 0 \text { : levels 1, 2, and } 3 \text { of } \\
\text { the original variable)] }\end{array}$ \\
\hline NPCOMP & $\begin{array}{l}\text { Intensity of nonprice competition (original and transformed } \\
\text { variables as for PCOMP) }\end{array}$ \\
\hline $\begin{array}{l}\text { MANUFACT, MOD_SERV, } \\
\text { TRAD_SERV }\end{array}$ & $\begin{array}{l}\text { Dummies for three sectors [manufacturing (MANUFACT); } \\
\text { modern services (MOD_SERV); traditional services } \\
\text { (TRAD_SERV); reference sector: construction] }\end{array}$ \\
\hline Y2003, Y2006 & $\begin{array}{l}\text { Time dummies for the years } 2003 \text { and 2006, respectively } \\
\text { (reference year: 2000) }\end{array}$ \\
\hline INSAMPLE_03 & Firm is still in the sample in cross section 2003 yes/no \\
\hline INSAMPLE_06 & Firm is still in the sample in cross section 2006 yes/no \\
\hline INSAMPLE_NEXT_PERIOD & Firm is still in the sample in the next cross section yes/no \\
\hline
\end{tabular}

cannot be applied to our data. Our main variables describing the founder characteristics have no variation over time within a firm. Hence, these variables would be wiped out when applying a fixed-effects estimator and we would not be able to identify the effects of the founder characteristics (see Raymond et al., 2010 for a detailed discussion on this issue). To deal with unobserved firm heterogeneity 


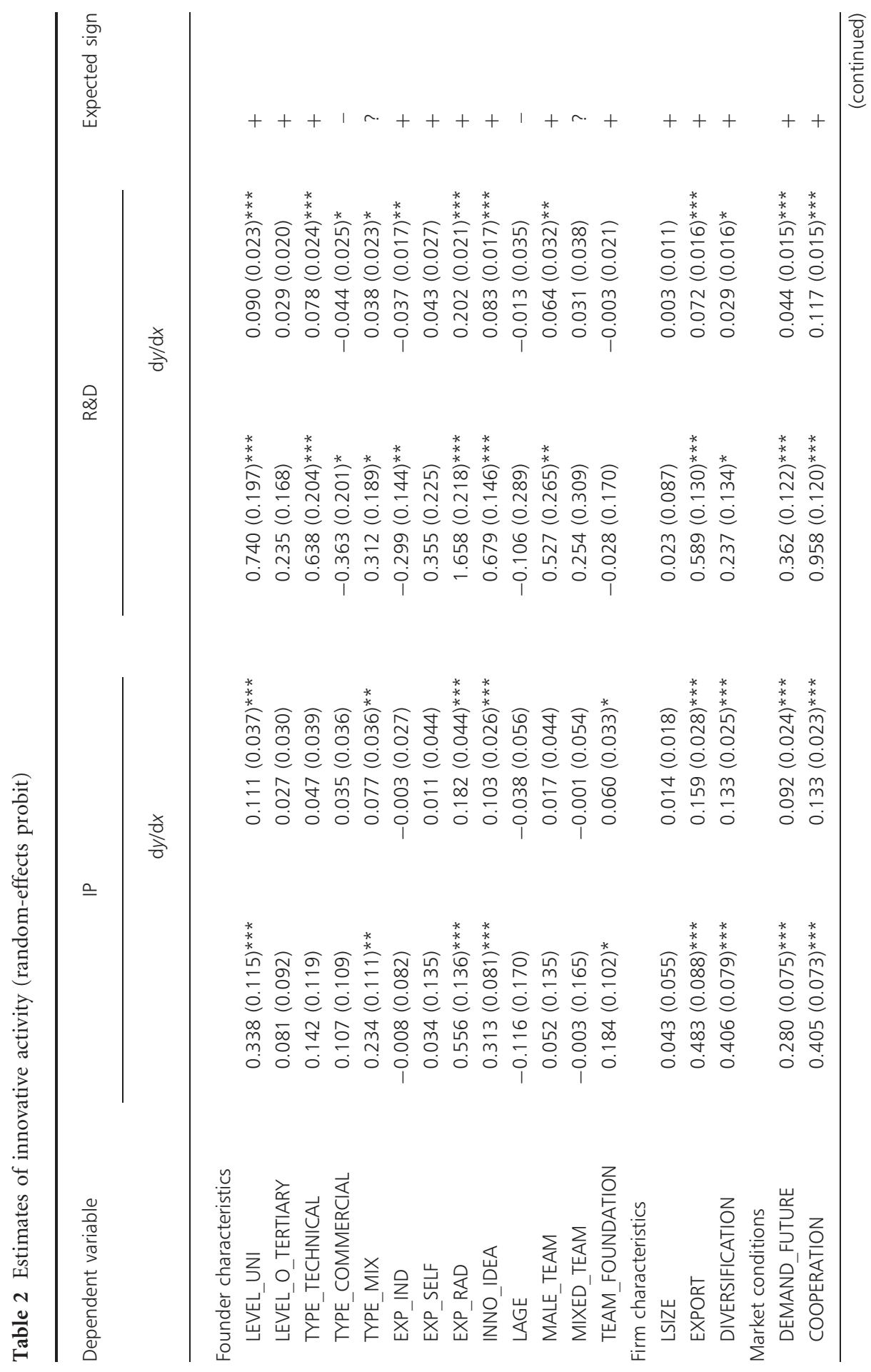




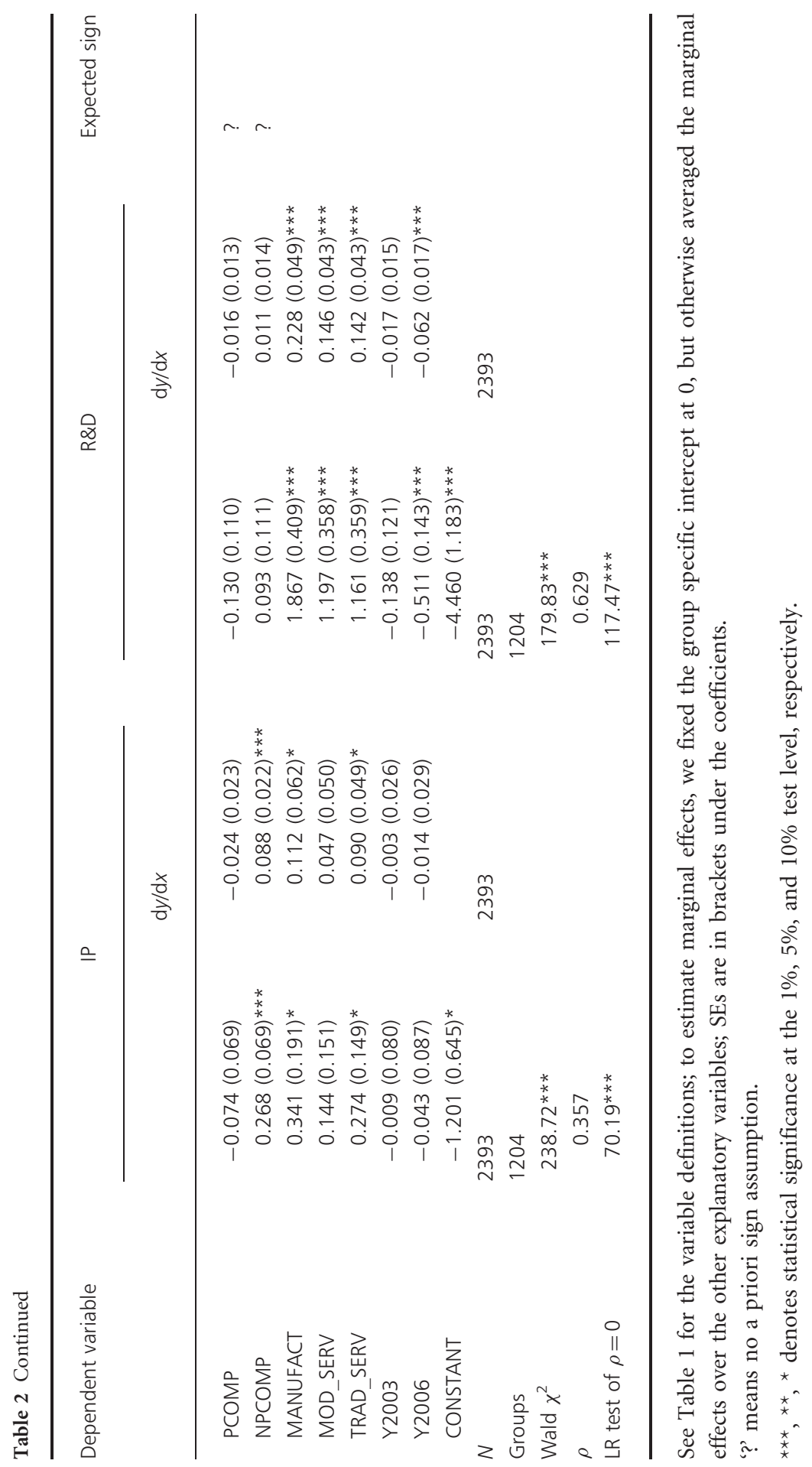


through individual effects, we estimate random-effects models where the likelihood functions are calculated by Gauss-Hermite quadratures.

\subsection{Endogeneity}

A further potential problem is the possible endogeneity of some of the right-hand variables that would imply inconsistent estimates. Since the data dealing with the founder characteristics refer to the point of time of the firm foundation and remain constant over time, our main results should at least not be affected by reverse causality. However, endogeneity may still be a problem, as we cannot eliminate the potential problem of initial conditions. The only straightforward way to solve the initial conditions problem — run a fixed effects model—is ruled out because we have no over-time variation in founder characteristics. As a consequence, we refrain from making causal claims. Instead, our estimation results are interpreted as partial correlations.

Finally, as one can see in the correlation matrix in Table A3 in Appendix A, the results are also not driven by multicollinearity.

\section{Results}

\subsection{Factors influencing the innovation performance of start-ups}

\subsubsection{General pattern}

The results of the random-effects estimates are reported in Table 2. Columns (1) and (3) show the estimated coefficients and the corresponding SEs. Columns (2) and (4) show average marginal effects.

Team foundations (TEAM_FOUNDATION) perform better with respect to innovation output, but not with respect to innovation input. Thus, $\mathrm{H} 1$ is confirmed, at least for innovation output. This result is quite similar to the one for education types (see below). A mix of qualification types as well as a combination of more than one founding individuals correlate positively with the introduction of innovative products.

Primarily, we are interested in the influence on innovative activities exerted by the variables describing the specific founder characteristics. As expected, the education level of the firm founders shows a positive correlation with innovation activities of the start-ups. Firms with a majority of founders that have a university degree (LEVEL_UNI) have significantly more innovative activities. A shift from a founding team that predominantly comprises persons that do not have (academic) university education to a team, in which most members have such education, is correlated with an increase of $11.1 \%$ and $9 \%$ of the likelihood that the firm introduces innovative products and conducts $\mathrm{R} \& \mathrm{D}$ activities, respectively. Interestingly, we can observe such an effect only for university education. The impact of the variable for 
tertiary-level education other than academic university education (LEVEL_O_TERTIARY), such as a degree from universities of applied science, is not statistically significant. Thus, $\mathrm{H} 2$ is confirmed, at least for university education.

The estimates in Table 2 corroborate only partly H3, namely with respect to R\&D activities. For start-ups with a founding team with pronounced technical know-how (TYPE_TECHNICAL), a significantly positive correlation with R\&D propensity is found, while for new firms that have founders with primarily commercial know-how (TYPE_COMMERCIAL) the estimates show a negative correlation with R\&D propensity. We could not find significant effects of these two variables for the output variable IP. The founders' technical background might be positively related with $\mathrm{R} \& \mathrm{D}$ activities but is apparently not a necessary precondition for innovation output. Moreover, our results demonstrate that a mix of both qualification types (TYPE_MIX) is required for having R\&D activities as well as for being able to introduce innovative products.

$\mathrm{H} 4$ is not confirmed as the results for the variable EXP_IND demonstrate. The effect of industry experience on innovation output IP is statistically insignificant, while the effect on R\&D activities is significantly negative. A reason for this negative effect may be that teams with industry experience are less inclined to conduct R\&D than founders with research background. In our sample, $<3 \%$ of the firms have at the same time industry experience and R\&D experience. However, as industry experience helps people to find market niches, it is not surprising that firms that have founders with industry experience do not show, despite less R\&D experience, significantly less innovation output.

The coefficient of the variable for self-employment experience (EXP_SELF) is statistically insignificant. The expected positive effect of accumulation of business skills is discernible only in the early years. In estimates of the model separately for each cross section, we find that in the first period 1996/1997-2000 founding teams with self-employment experience have significantly more innovative activities (innovation input as well as innovation output) than other teams. In the later stages, the effect becomes insignificant. This is an intuitively plausible result, as particularly in the first period self-employment experience helps to limit costs of administrative tasks so that more time is available for innovative activities. With increasing firm age other teams also gain such experience, wherefore the advantage disappears. Thus, H5 receives only partial confirmation.

The strongest effect on innovative activities as measured by the respective marginal effect is found for the variable that measures R\&D experience (EXP_RAD). The availability of such innovation-specific know-how increases the probability of innovation input and innovation output by $20.2 \%$ and $18.2 \%$, respectively. The coefficient of the variable for concrete innovation-relevant ideas from prior occupations (INNO_IDEA) is also positive and statistically significant. Firms that were founded in order to realize concrete ideas for innovations from the founder's former occupation (either in research or in business) have on average an $8.3 \%$ and $10.3 \%$ higher 
probability of innovation input and innovation output, respectively, than firms without such ideas. Therefore, the $\mathrm{H} 6$ and $\mathrm{H} 7$ are clearly confirmed by our estimates.

In the pooled data set, the effect of the average age of the founders (LAGE) is statistically insignificant. However, as we will see in Section 5.3, the effect of the risk behavior of the firm founders becomes significant when investment in R\&D is persistent; persistent innovation activities are negatively correlated with the average age of the firm founders (see column 4 in Table 5).

As expected, we find a positive sign for founding teams consisting only of male persons. However, the effect is statistically significant only for $\mathrm{R} \& \mathrm{D}$ activities. Thus, start-ups with only male team members (MALE_TEAM) show a higher propensity to perform R\&D than firms with exclusively female members or firms with founding teams that are mixed with respect to gender.

Finally, the results for the other variables are in line with the expectations. Exporting firms (EXPORT), firms with product diversification (DIVERSIFICATION), firms with cooperation (COOPERATION) and firms that expect a positive development of the firm-specific product demand (DEMAND_ FUTURE) tend to a higher innovation propensity than firms without such characteristics. While intensive nonprice competition (NPCOMP) correlates positively with innovation output, no effect is found for the intensity of price competition (PCOMP).

Not surprisingly, sector affiliation is related to R\&D activities. Firms in the manufacturing sector have significantly more R\&D activities than firms in other sectors. Further, there is more $\mathrm{R} \& \mathrm{D}$ activity in the service sector than in the construction sector. Contrary to expectation, firm size (LSIZE) does not affect innovative activities. As the observed start-ups are for the most part small firms, little variance in firm size may be the reason for this result.

On the whole, estimation results show that innovative activities of start-ups are strongly related to the characteristics of the firm founders. Innovation capability of the founders is primarily determined by the education level (LEVEL_UNI), R\&D experience (EXP_RAD) and the availability of concrete innovation-relevant ideas from earlier occupations (INNO_IDEA).

\subsubsection{Mutually reinforcing effects of firm founders' characteristics}

The strong impact of the founder characteristics becomes even clearer, when we analyze the effect of combinations of these three variables within a firm. In Table 3, we estimated once more the innovation input and the innovation output model inserting now instead of the original variables for university-level education, $R \& D$ experience and the availability of innovation-relevant ideas all six possible combinations of these variables (reference group: firms without any of these characteristics), including the "pure" cases with only one characteristic [combinations: u1_r0_i0 (university-level education); u0_r1_i0 (R\&D experience); u0_r0_i1 (innovative ideas) in Table 3]. Not astonishingly, the "pure" effects are smaller than the "mixed" 


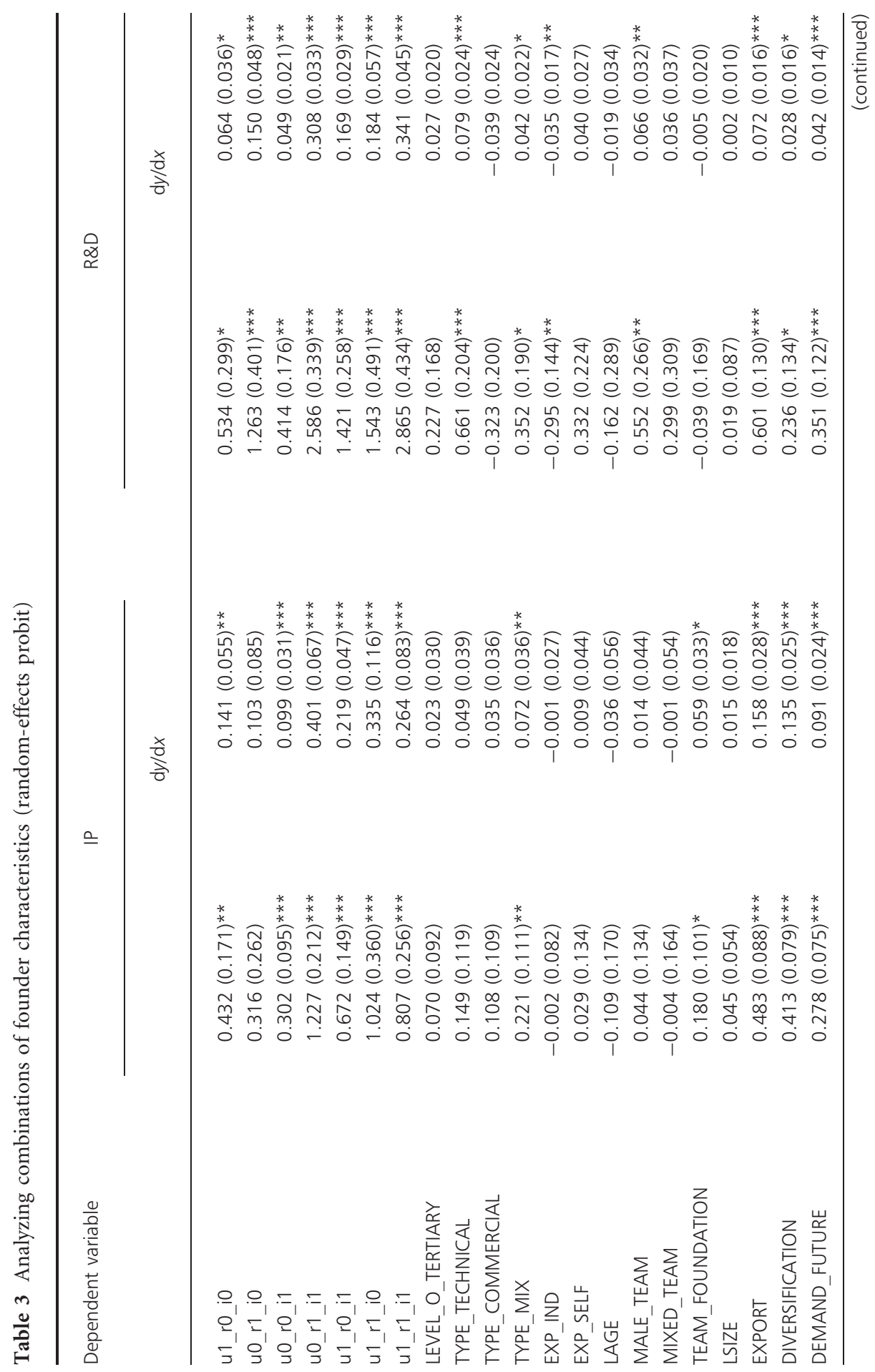




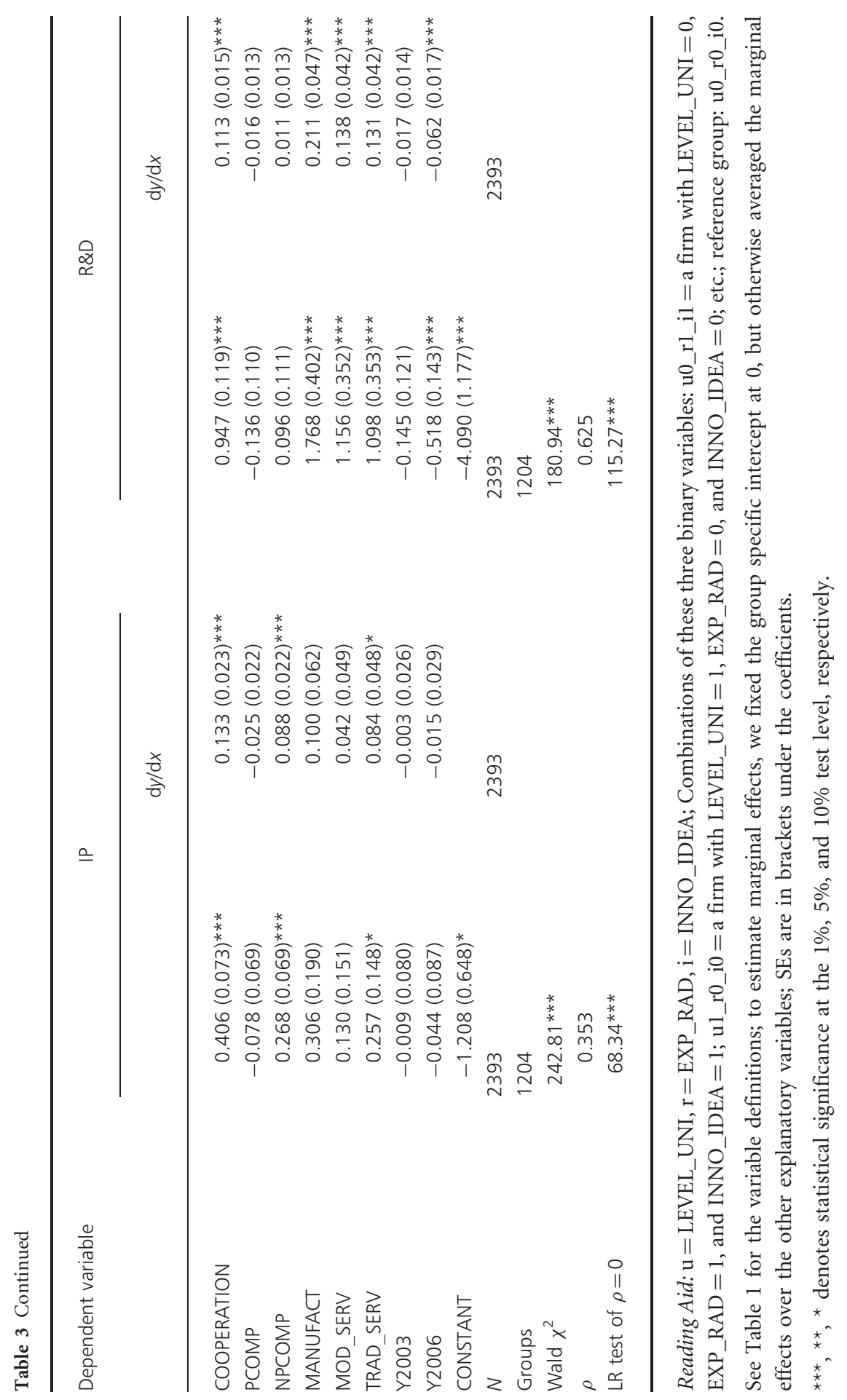


effects in Table $2 .^{6}$ At the maximum, combinations of these factors increase the probability of innovation output by $>40 \%$ (combination u0_r1_i1; R\&D experience and innovative ideas) and the probability of performing R\&D by nearly $35 \%$ (combination u1_r1_i1; all three characteristics).

For innovation output, all three combinations of two characteristics show marginal effects that are larger than the pure effects of each of the underlying characteristics. In two cases- the combinations " $R \& D$ experience/innovative ideas" and "R\&D experience/university-level education" - these effects are larger than the sum of the underlying pure effects, thus indicating the existence of mutually reinforcing effects of the respective pairs of characteristics. This is not the case for the combination "university-level education/innovative ideas."

Taken as a whole, there is a hint for the existence of complementarity of the underlying pairs of characteristics, $\mathrm{R} \& \mathrm{D}$ experience being a necessary ingredient of the reinforcing combinations. Innovative ideas and university-level education alone are not enough for such a reinforcing effect. This conclusion is further strengthened by the result for the combination of all three characteristics. In this case, the marginal effect is smaller than the respective effect for the combination of the two characteristics "university-level education" and "R\&D experience," which means that having the third characteristic (innovative ideas) together with the other two characteristics even decreases the likelihood of generating innovation output.

Turning now to $R \& D$, we find that also in this case two of the three two-characteristic combinations show a mutually reinforcing effect: "R\&D experience/innovative ideas" (as for innovation output) and "university-level education/ innovative ideas." Contrary to innovation output, the three-characteristic combination yields in this case a mutually reinforcing effect. Education and innovative ideas are not sufficient for performing $\mathrm{R} \& \mathrm{D}$, obviously it needs in addition experience in R\&D.

There is a policy implication of these results: it is advisable for public agencies supporting the foundation of new innovative firms that they would take these mutually reinforcing effects of founders' characteristics into account when assessing projects of start-ups.

\subsection{Influence of changes in the composition of founding teams}

Over time, changes in the composition of the founding teams (that are at the same time also management teams of the firms) are possible. The firms reported the

\footnotetext{
${ }^{6}$ This means that team composition that is successful in terms of innovation performance is driven by differences and diversification of characteristics, not similarity. This result has important implications for further research on founding teams. Many empirical studies come to the conclusion that there is a natural tendency of founding teams to prefer a homogeneous than a heterogeneous composition, even if homogeneity is not conducive to performance (see Ruef et al., 2003 and the discussion of this issue there).
} 
characteristics of the founding team at the time of firm foundation, so it is possible that some of these factors may change later. The results of the estimates excluding firms with changes in the composition of the founding team are reported in Table 4. In the innovation output model, the effect of team foundations (TEAM FOUNDATION) disappears. This means that the team effect found in Table 2 is traced back primarily to firms with changes in the composition of the founding team. In the R\&D model, the variable for other tertiary level education (LEVEL_O_ TERTIARY) now is positively correlated with $\mathrm{R} \& \mathrm{D}$ activities (the effect of LEVEL_O_TERTIARY is however significantly smaller than the effect of LEVEL_UNI). On the other hand, the effect of commercial know-how (TYPE_ COMMERCIAL) becomes insignificant. We also find a significant positive effect of self-employment experience (EXP_SELF) that can be interpreted as a hint that this effect is discernible only for firms that kept their founding team, thus also their management team, unchanged.

Despite the fact that $>20 \%$ of the firms reported changes in their management teams, excluding firms with such changes does only marginally affect our estimates.

\subsection{Persistently innovative start-ups}

So far we have considered all firms that have had innovation activities in some point of time. However, it would be interesting to know whether founder characteristics also correlate with the persistence of innovation over time. In order to investigate such differences, we estimate a multinomial logit model including only firms that answered all three questionnaires and choose the base category so that we can analyze whether the effects of founder characteristics differ for firms that have in each cross section (persistently) innovative activities from firms with discontinuous innovative activities. ${ }^{7}$ Estimation results for firms without innovation activities in any point of time confirm previous results (columns 1 and 3 in Table 5). The reduction of the sample size thus does only marginally affect the estimation results.

The results for the firms with continuous innovation activities show that founder characteristics are not the main factors correlating with the persistence of innovation in start-ups (see columns 2 and 4 of Table 5). The coefficients of all founder characteristics variables are statistically insignificant in the innovation output estimates, only a few of them are significant in the innovation input estimates. R\&D experience (EXP_RAD) seems to be significantly more important in firms that have had in each cross section R\&D activities than in firms with discontinuous R\&D activities. Further, founding teams with a high average age (LAGE) tend to invest less in innovation input. This is intuitively plausible, as investment costs increase with

\footnotetext{
${ }^{7}$ See the note in Table 5 for the construction of the dependent variables for the multinomial logit model. Because we do not have enough observations for each of the three categories to test the gender effect in detail as in the previous models, we include just a single variable measuring the dominant gender of the founding team (GENDER) in the estimates in Table 5.
} 


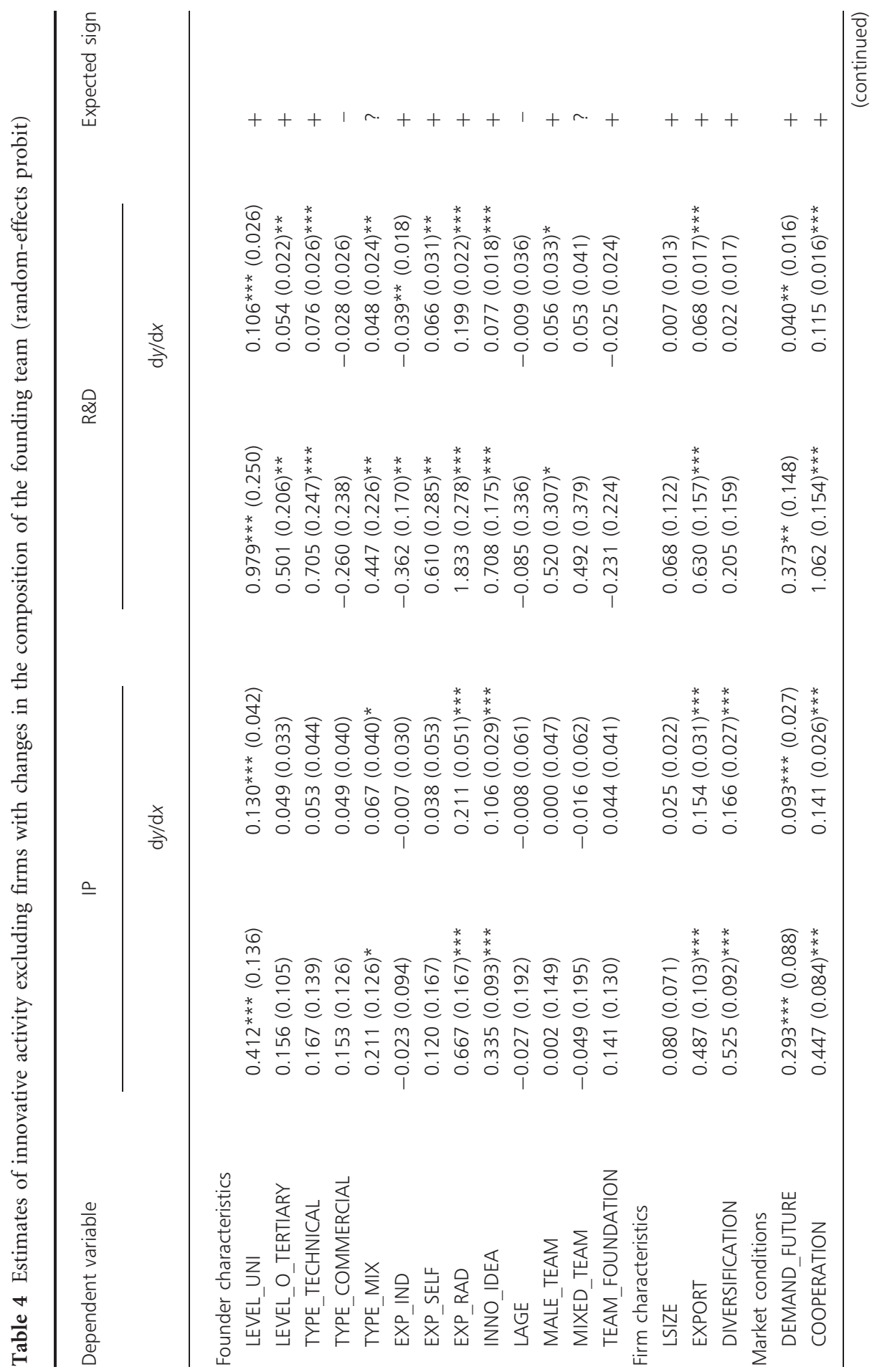




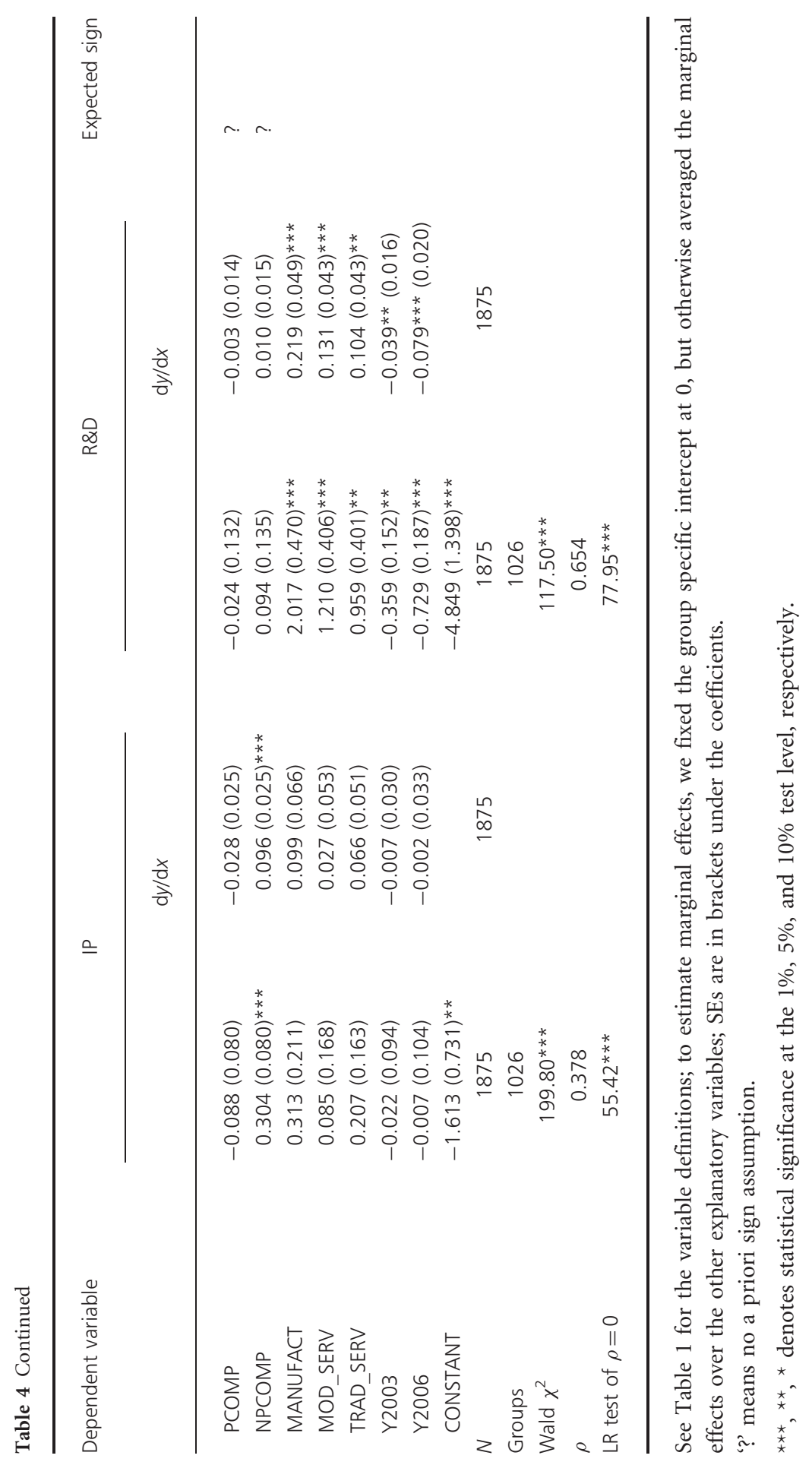




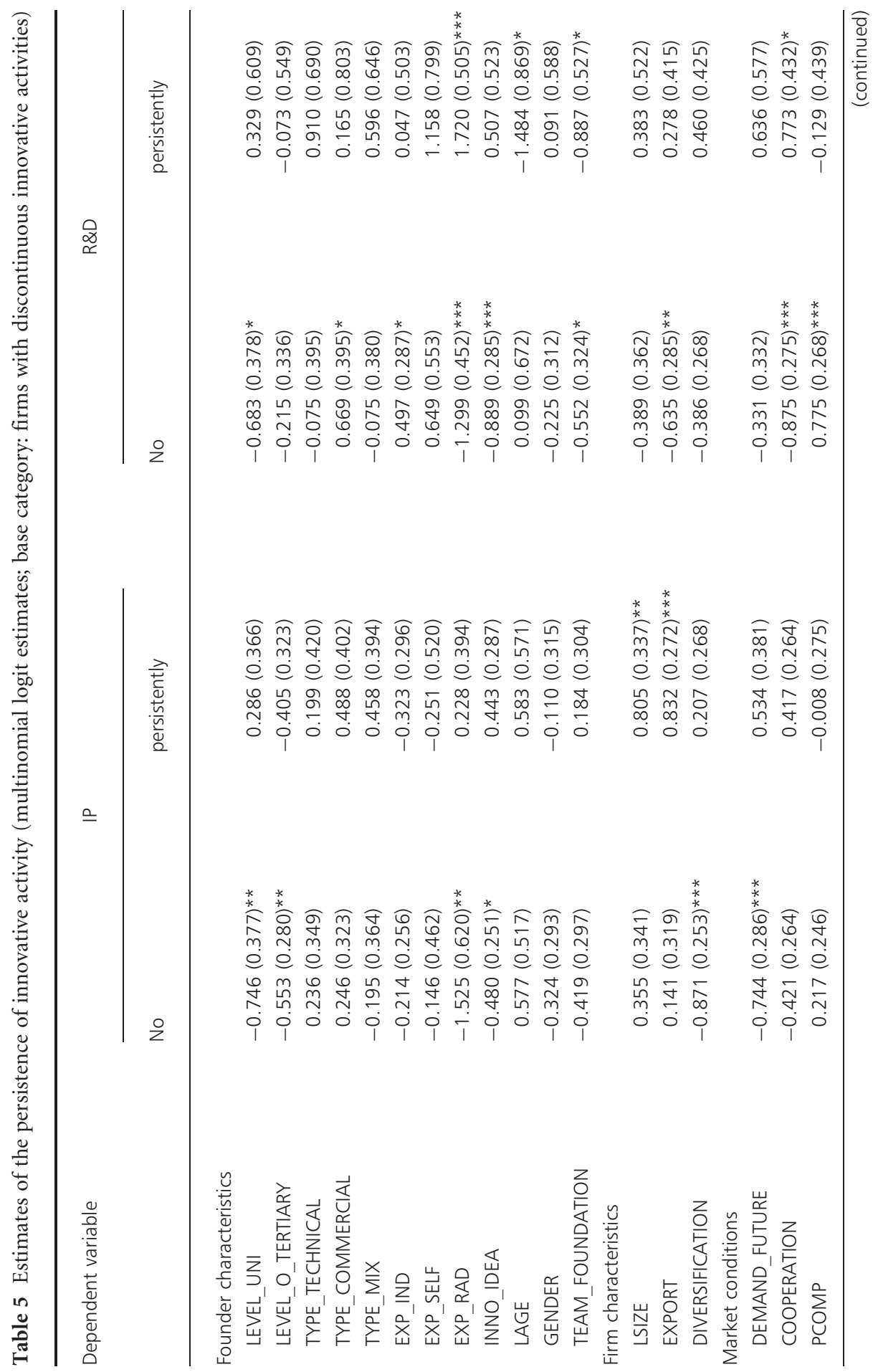




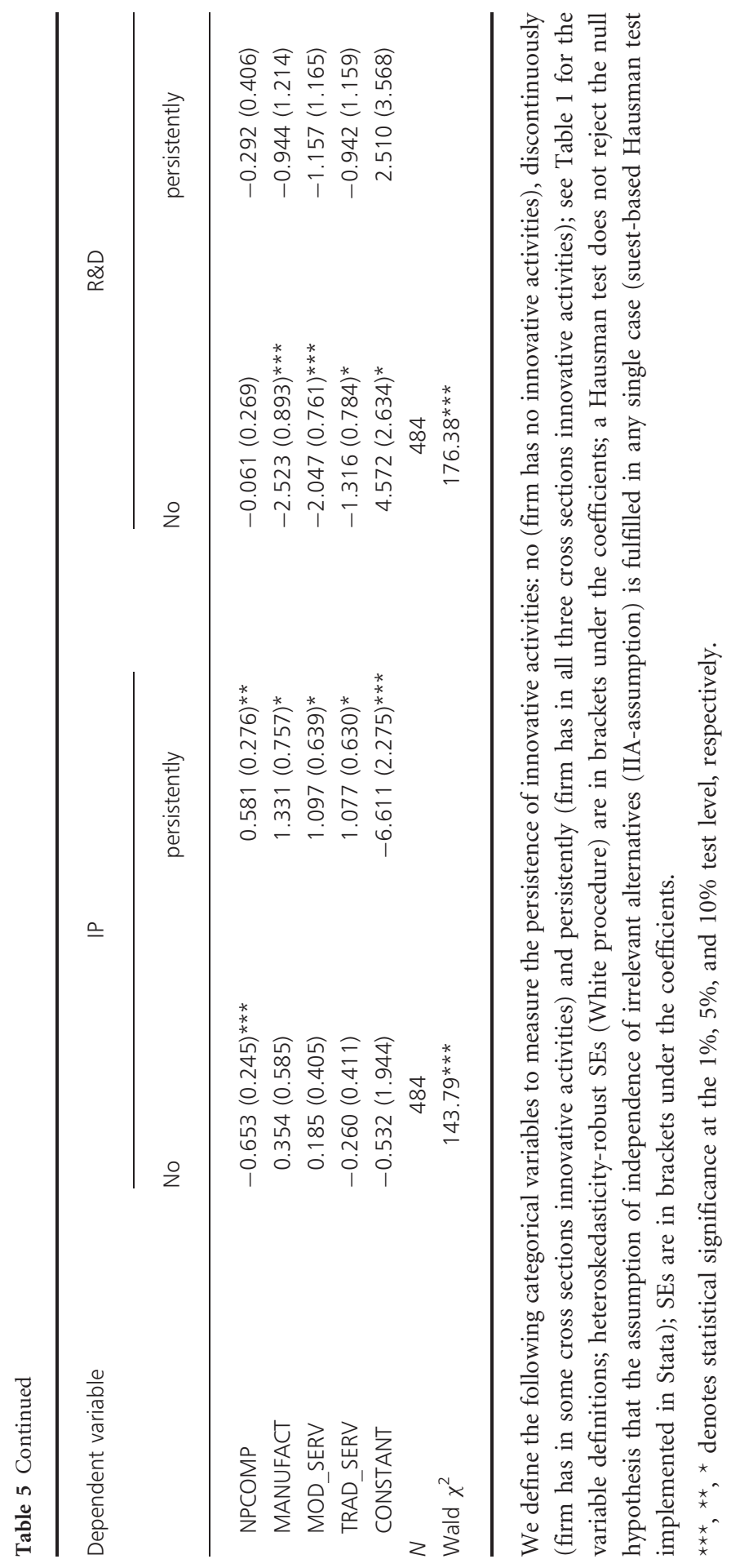


persistent innovation activities, whereby risk behavior of the firm founders gets even more important. Surprisingly, we find a weak negative effect of team foundations (TEAM_FOUNDATION) on the persistence of R\&D activities. However, this effect is primarily driven by a strong correlation with the variable LSIZE $(r=0.33)$. While this correlation does not affect the results in the estimates based on all observations, in this regression the significant negative effect for the variable TEAM FOUNDATION disappears, when we do not control for firm size.

In sum, we conclude that the founders' characteristics are primarily related to the likelihood of a firm getting engaged in innovative activities but not to the persistence of such innovative activities over time.

Firm size (LSIZE) is positively correlated with innovation persistence. Further factors with (partly) positive effects either on innovation output or innovation input are the degree of exposition to international competition as measured by the existence of exporting activities (EXPORT), the intensity of nonprice competition (NPCOMP), and finally the existence of cooperation with other firms/institutes (COOPERATION).

\subsection{Comparison with existing empirical literature}

We could find only two empirical studies that deal with the innovation capabilities of firm founders in start-ups. A third study comes near to our topic as it investigates the influence of human capital and other related founders' characteristics on the growth perspectives of new technology-based firms.

The first one is the study of Lynskey (2004) that analyzes the impact of the CEO characteristics based on Japanese firm-level data. In this study, innovative activity is measured by the number of patent applications and the number of new products. Such characteristics are age, level of formal education, previous management experience, and previous experience in R\&D, especially in research networks. An additional variable denotes whether the CEO is also the founder of the firm, so that possible differences between these two functions can be captured. However, in the new product regression no variable significantly correlated, while in the estimates based on the number of patents only $\mathrm{R} \& \mathrm{D}$ experience and experience with research networks positively showed a positive effect.

In contrast with our results, managerial characteristics show no explanatory power in these models. An explanation could be that the firms in their sample are much larger than our firms. It is sensible to assume that the CEO is less directly involved in the innovation process in larger firms than in smaller firms, so that the influence of the CEO's characteristics is more limited.

In a second study, Koch and Strotmann (2008) analyze the impact of founder characteristics on the innovation performance of German start-ups in the knowledge-intensive business sector. They distinguish two categories of innovation performance, incremental innovation, and radical innovation. As independent 
variables they include variables describing the characteristics of firm founders such as age, sex, and also information whether a concrete idea from the founder's former occupation was decisive for the foundation, what is similar to the variable INNO_IDEA in our study. It is also controlled for tam foundations.

Male founders tend to have more radical innovations than female founders and firms of founders that were self-employed before foundation have fewer innovations (incremental and radical) than firms of founders that worked in the private economy. All other variables that describe the founder characteristics do not significantly affect the innovation performance. The differences to our results may be traced back to the inadequate measurement of the professional ground of teams $(\sim 60 \%$ of the firms were team foundations) based just only on the information of a single founding person.

Based on a sample of 506 Italian young firms in high-tech industries in both manufacturing and services, Colombo and Grill (2005) find that the nature of the education and of prior experience of founders exert a significant positive influence on firms' economic performance. Even if the target variable is not the same as in our study (employment growth versus innovation performance), the results point in the same direction as ours.

\section{Conclusions}

As most start-ups are not growth-drivers, the allocation of start-up subsidies has important policy implications. Misallocation may keep inefficient firms on the market and/or lead to a crowding out effect of nonsubsidized firms. Policy makers should thus focus on firms with high growth potential and stop subsidizing typical start-ups (Shane, 2009). Accordingly, it is important to be able to identify firms with a high probability of enhancing economic growth. As innovation performance is a crucial precondition for the growth of such firms, identifying factors that determine whether a young firm would have innovative activities or not seems to be an important step in this direction. So far it is unclear how innovative start-ups look like. In this article, we investigate whether information on the founder characteristics is correlated with the innovative activity of start-ups.

Following pattern emerges from our estimates: the ability of start-ups to conduct $\mathrm{R} \& \mathrm{D}$ and introduce innovative products depends on founders having a university education (at best mixed technical and commercial), prior experience in R\&D, andespecially important—strong motivation to realize their own innovative ideas. There are also mutually reinforcing effects of these three characteristics, especially with respect to $\mathrm{R} \& \mathrm{D}$ activities. Team foundations perform better than single founders with respect to sales of innovative products, but not with respect to $R \& D$.

All in all, we conclude that knowing the founder characteristics would help policy makers to identify the innovative start-ups already in the beginning and thus to 
increase efficiency of start-up subsidies, given that such a promotion policy is pursued. A further reason to use founder characteristics as selection criteria for subsidies is that they are easily observable and remain constant over time. Accordingly, the identification of innovative start-ups would be possible at relatively low costs. This applies all the more as changes in the composition of the founding team have no discernible influence on the innovation activities of the firms. On the other hand, the use of these variables as identification variables may be limited, as founder characteristics seem to determine whether a firm gets engaged in innovative activities but not whether such activities are persistent over time (with the exception of experience in R\&D). Based on founder information, it is not possible to distinguish between start-ups that have persistent innovation activities and firms with discontinuous innovation activities.

Further research is needed to better understand the factors that allow start-ups to innovate persistently, thus to yield a discernible contribution to technological renewal. In addition, comparative studies based on firm data for different countries with different entrepreneurial cultures would enable us to capture more innovation-relevant traits of founding persons and generalize our results.

\section{Acknowledgements}

The fruitful comments and suggestions of two anonymous referees of this journal as well as the attendants of the session of the Conference of European Association of Research in Industrial Economics (EARIE), Stockholm, September 1-3, 2011, in which the article was presented, are gratefully acknowledged.

\section{References}

Acs, Z. J. and D. Audretsch (1990), Innovation and Small Firms. The MIT Press: London.

Aghion, P., R. Blundell, R. Griffith, P. Howitt and S. Prantl (2009), 'The effects of entry on incumbent innovation and productivity,' The Review of Economics and Statistics, 91(1), $20-32$.

Åstebro, T. and I. Bernhardt (2005), 'The Winner's curse of human capital,' Small Business Economics, 24(1), 63-78.

Barker, V. L. and G. C. Mueller (2002), 'CEO characteristics and firm R\&D spending,' Management Science, 48(6), 782-801.

Barney, J. (1991), 'Firm resources and sustained competitive advantage,' Journal of Management, 17(1), 99-120.

Barringer, B.R., F. F. Jones and D. O. Neubaum (2004), 'A quantitative content analysis of the characteristics of rapid-growth firms and their founders,' Journal of Business Venturing, 20(5), 663-687. 
Bergmann Lichtenstein, B. M. and C. G. Brush (2001), 'How do resource bundles develop and change in new ventures? A dynamic model and longitudinal exploration,' Entrepreneurship: Theory and Practice, 25(3), 37-58.

Bosma, N., E. Stam and V. Schutjens (2011), 'Creative destruction and regional productivity growth: evidence from the Dutch manufacturing and services industries,' Small Business Economics, 36(4), 401-418.

Brüderl, J., P. Preisendorfer and R. Ziegler (1992), 'Survival chances of newly founded organizations,' American Sociological Review, 57(2), 227-242.

Brüderl, J., P. Preisendörfer and R. Ziegler (2007), Der Erfolg neugegründeter Betriebe: Eine empirische Studie zu den Chancen und Risiken von Unternehmensgründungen. Duncker and Humblot: Berlin.

Cantner, U. and S. Kösters (2011), 'Picking the winner? - empirical evidence on the targeting of R\&D subsidies to start-ups,' Small Business Economics, forthcoming.

Capaldo, G., L. Iandoli, M. Raffa and G. Zollo (2003), 'The evaluation of innovation capabilities in small software firms: a methodological approach,' Small Business Economics, 21(4), 343-354.

Carpenter, M., T. Pollock and M. Leary (2003), 'Testing a model of reasoned risk-taking: governance, the experience of principals and agents, and global strategy in high-technology IPO firms,' Strategic Management Journal, 24, 803-820.

Chen, H. L., W. T. Hsu and Y. S. Huang (2010), 'Top management team characteristics, R\&D investment and capital structure in the IT industry,' Small Business Economics, 35(3), 319-333.

Colombo, M. G. and L. Grilli (2005), 'Founders' human capital and the growth of new technology-based firms: a competence-based view,' Research Policy, 34(6), 795-816.

Eckel, C. C. and P. J. Grossman (2002), 'Sex differences and statistical stereotyping in attitudes toward financial risk,' Evolution and Human Behavior, 23(4), 281-295.

Fabel, O. (2004), 'Spin-offs of entrepreneurial firms: an o-ring approach,' Journal of Institutional and Theoretical Economics, 160(3), 416-438.

Foss, N. J. (1993), 'Theories of the firm: contractual and competence perspectives,' Journal of Evolutionary Economics, 3(2), 127-144.

Fritsch, M. and A. Schroeter (2009), 'Are more start-ups really better? Quantity and quality of new businesses and their effect on regional development,' Jena Economic Research Papers 2009-070, Friedrich-Schiller-University Jena, Max-Planck-Institute of Economics.

Hadjimanolis, A. (2000), 'A resource-based view of innovativeness in small firms,' Technology Analysis and Strategic Management, 12(2), 263-281.

Hambrick, D. C. and P. A. Mason (1984), 'Upper echelons: the organization as a reflection of its top managers,' The Academy of Management Review, 9(2), 193-206.

Horbach, J. (2008), 'Determinants of environmental innovation-New evidence from German panel data sources,' Research Policy, 37(1), 163-173. 
Jianakoplos, N. A. and A. Bernasek (1998), 'Are women more risk averse?' Economic Inquiry, 36(4), 620-630.

Katila, R. (2002), 'New product search over time: past ideas in their prime?' The Academy of Management Journal, 45(5), 995-1010.

Katila, R. and S. Shane (2005), 'When does lack of resources make new firms innovative?' Academy of Management Journal, 48(5), 814-829.

Kleinknecht, A., K. van Montfort and E. Brouwer (2002), 'The non-trivial choice between innovation indicators,' Economics of Innovation and New Technology, 11(2), $109-121$.

Koch, A. and H. Strotmann (2008), 'Absorptive capacity and innovation in the knowledge intensive business service sector,' Economics of Innovation and New Technology, 17(6), 511-531.

Lazear, E. (2005), 'Entrepreneurship,' Journal of Labor Economics, 23(4), 649-680.

Lechler, T. (2001), 'Social interaction: a determinant of entrepreneurial team venture success,' Small Business Economics, 16(4), 263-278.

Lynskey, M. J. (2004), 'Determinants of innovative activity in Japanese technology-based start-up firms,' International Small Business Journal, 22(2), 159-196.

Malerba, F. and S. Torrisi (1992), 'Internal capabilities and external networks in innovative activities. Evidence from the software industry,' Economics of Innovation and New Technology, 2(1), 49-71.

Marino, K. E. and A. F. De Noble (1997), 'Growth and early returns in technologybased manufacturing ventures,' Journal of High Technology Management Research, 8(2), $225-242$.

McGee, J. E., M. J. Dowling and W. L. Megginson (1995), 'Coperative strategy and new venture performance: the role of business strategy and management experience,' Strategic Management Journal, 16(7), 565-580.

Nerkar, A. and S. Shane (2003), 'When do start-ups that exploit patented academic knowledge survive?' International Journal of Industrial Organization, 21, 1391-1410.

Raymond, W., P. Mohnen, F. Palm and S. S. van der Loeff (2010), 'Persistence of innovation in Dutch manufacturing: is it spurious?' The Review of Economics and Statistics, 92(3), 495-504.

Rogers, M. (1998), The Definition and Measurement of Innovation. Melbourne Institute of Applied Economic and Social Research: Parkville, VIC.

Romijn, H. and M. Albaladejo (2002), 'Determinants of innovation capability in small electronics and software firms in southeast England,' Research Policy, 31(7), 1053-1067.

Roper, S. and J. H. Love (2002), 'Innovation and export performance: evidence from the UK and German manufacturing plants,' Research Policy, 31(7), 1087-1102.

Ruef, M, H. Aldrich and N. M. Carter (2003), 'The structure of founding teams: homophily, strong ties, and isolation among U.S. entrepreneurs,' American Sociological Review, 68(2), $195-222$. 
Schumpeter, J. A. (1934), The Theory of Economic Development. Harvard University: Cambridge.

Shane, S. (2000), 'Prior knowledge and the discovery of entrepreneurial opportunities,' Organization Science, 11(4), 448-469.

Shane, S. (2009), 'Why encouraging more people to become entrepreneurs is bad public policy,' Small Business Economics, 33(2), 141-149.

Shan, W. J., G. Walker and B. Kogut (1994), 'Interfirm cooperation and startup innovation in the biotechnology industry,' Strategic Management Journal, 15(5), 387-394.

Stam, E. and V. Schutjens (2006), 'The fragile success of team start-ups,' in R. Oakey, W. During and S. Kauser (eds), New Technology-Based Firms in the New Millennium, Vol. V, Elsevier Science: Oxford, pp. 219-233.

Thakur, P. T. (1999), 'Size of investment, opportunity choice and human resources in new venture growth: some typologies,' Journal of Business Venturing, 14(3), 283-309.

van Gelderen, M. W., A. R. Thurik and N. Bosma (2005), 'Success and risk factors in the pre start-up phase,' Small Business Economics, 24(4), 365-380.

Wooldridge, J. M. (2002), Econometric Analysis of Cross Section and Panel Data. The MIT Press: Cambridge, MA, London, England. 


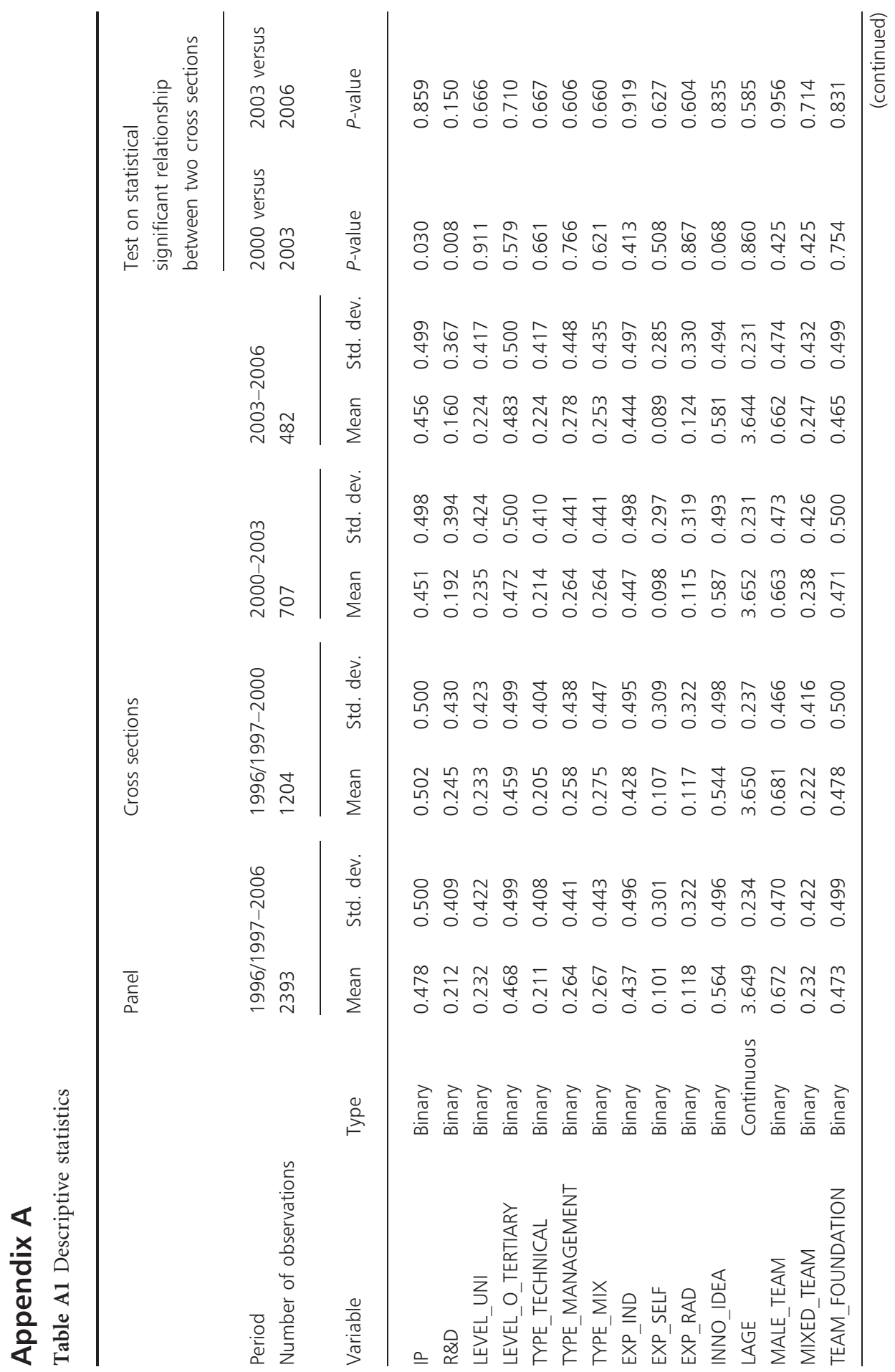




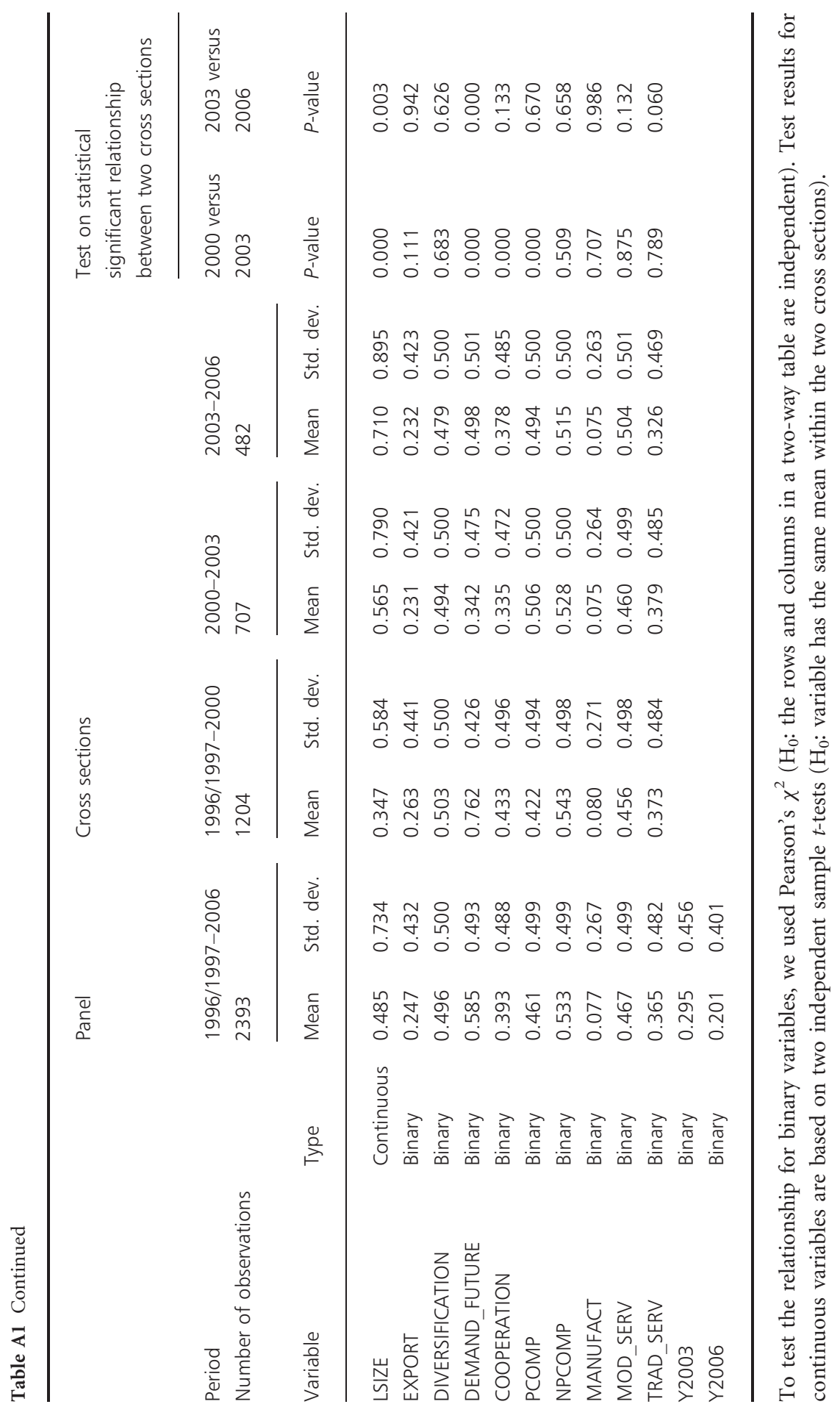




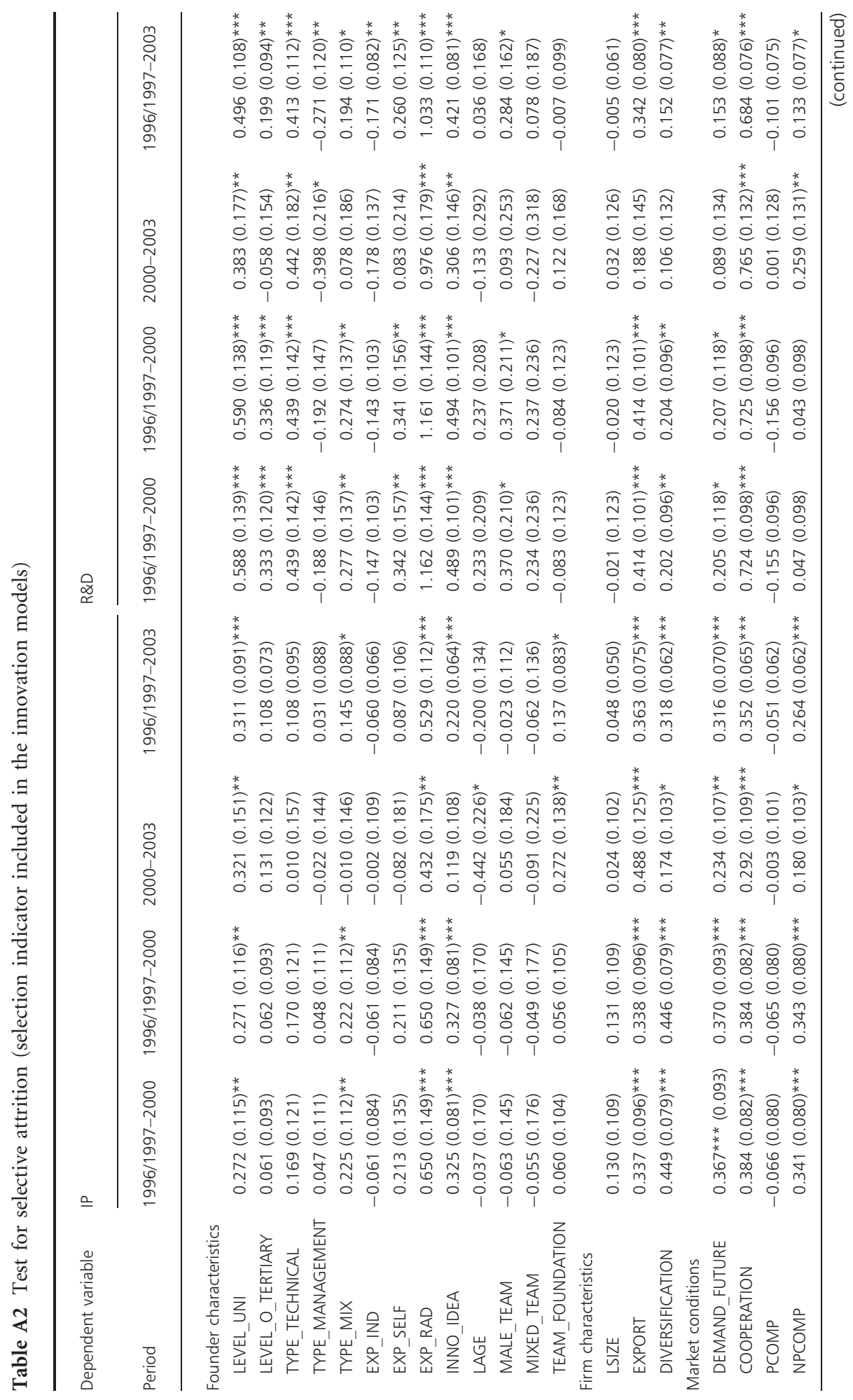




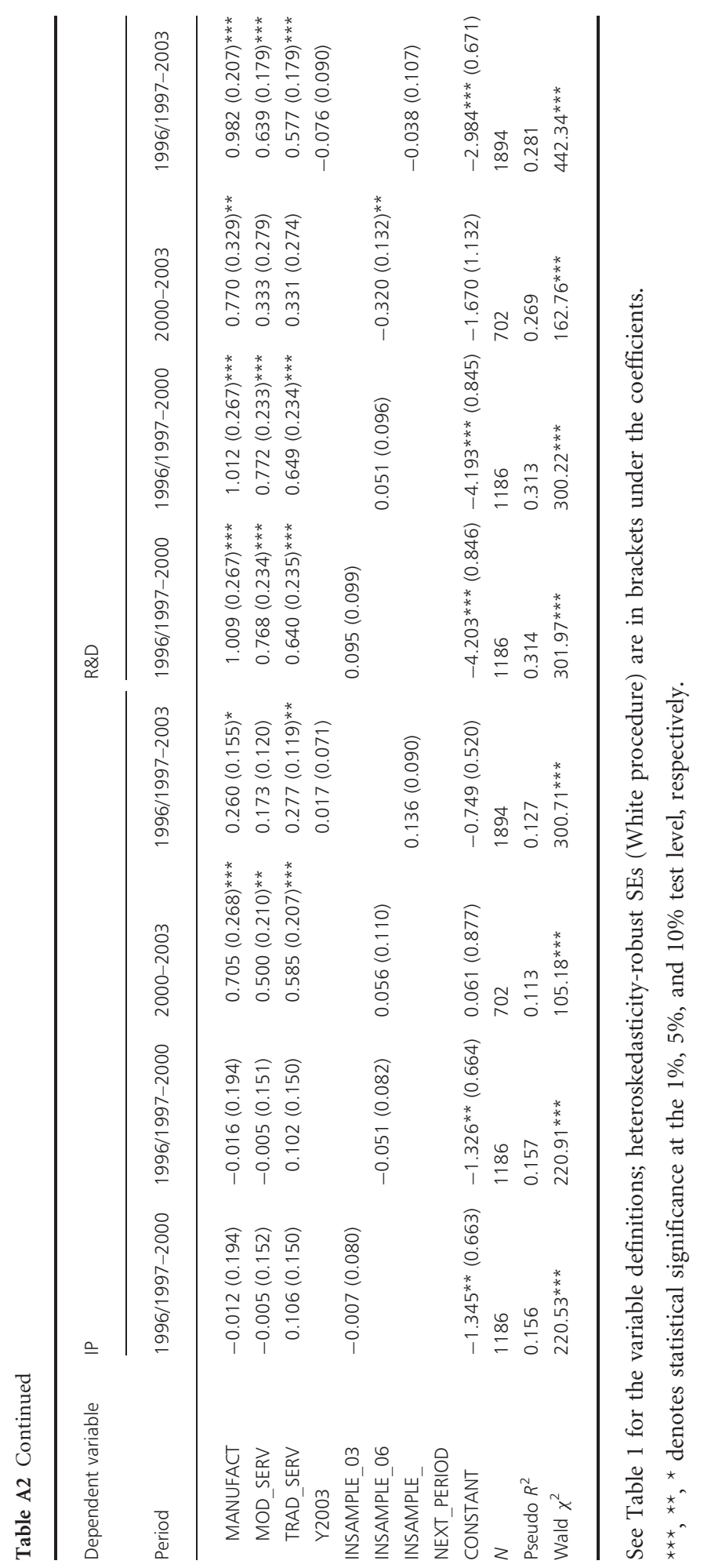




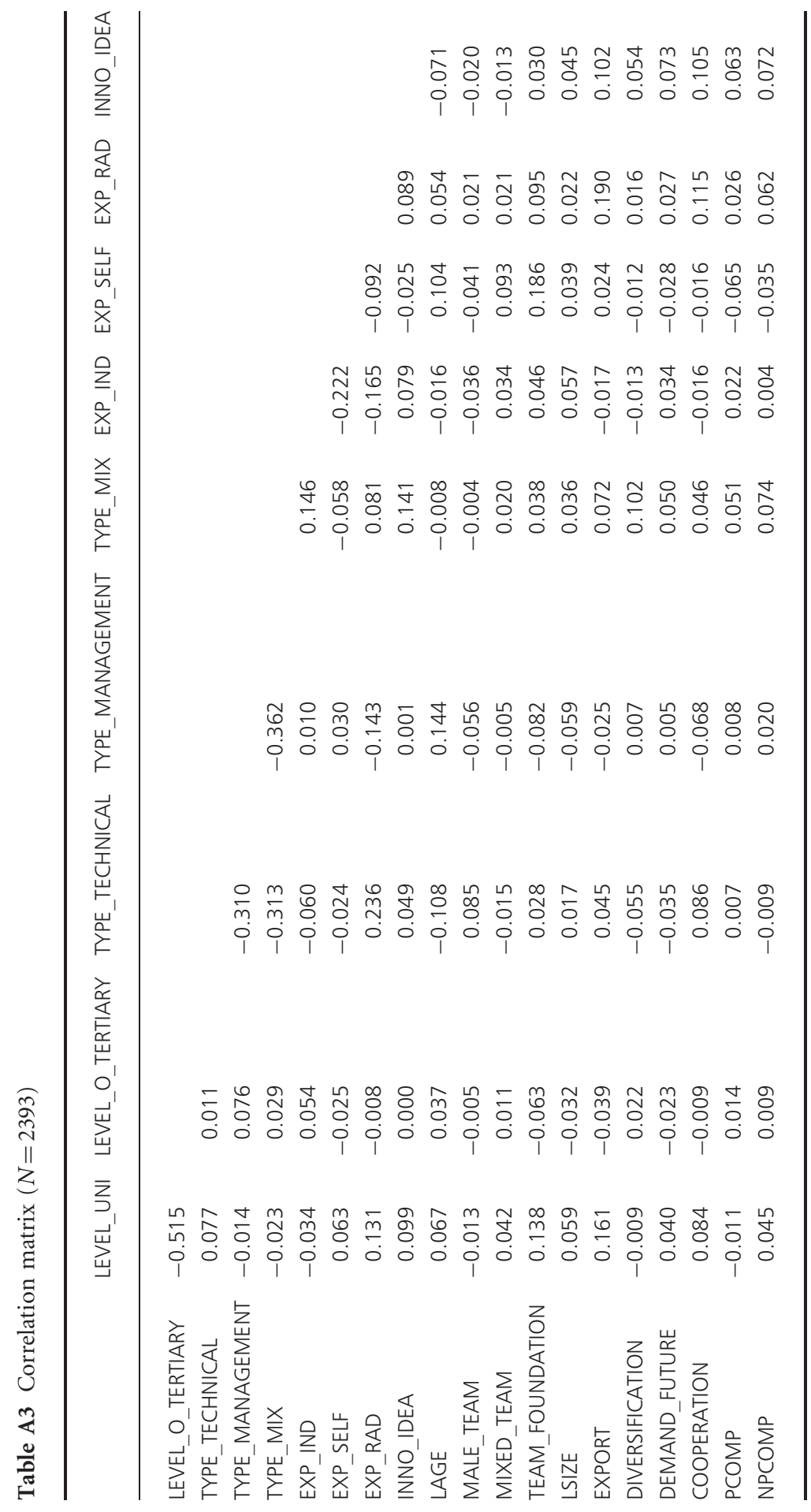


LAGE MALE_ MIXED_ TEAM__ LSIZE EXPORT DIVERSIFICATION TEAM TEAM FOUNDATION

\begin{tabular}{|c|c|c|c|c|c|c|c|}
\hline MALE_TEAM & -0.019 & & & & & & \\
\hline MIXED_TEAM & 0.030 & -0.786 & & & & & \\
\hline TEAM_FOUNDATION & -0.057 & -0.405 & 0.567 & & & & \\
\hline LSIZE & -0.039 & -0.005 & 0.065 & 0.320 & & & \\
\hline EXPORT & 0.082 & 0.029 & 0.009 & 0.062 & 0.069 & & \\
\hline DIVERSIFICATION & -0.026 & 0.029 & 0.044 & 0.026 & 0.074 & 0.104 & \\
\hline DEMAND FUTURE & -0.061 & 0.013 & 0.022 & 0.061 & 0.010 & 0.073 & 0.093 \\
\hline COOPERATION & -0.046 & 0.041 & 0.039 & 0.098 & 0.042 & 0.177 & 0.154 \\
\hline PCOMP & -0.045 & -0.039 & 0.059 & 0.079 & 0.046 & -0.016 & 0.028 \\
\hline NPCOMP & -0.014 & -0.005 & 0.047 & 0.043 & 0.043 & 0.056 & 0.040 \\
\hline
\end{tabular}

\begin{tabular}{lrll}
\hline & DEMAND_FUTURE & COOPERATION & PCOMP \\
\hline COOPERATION & 0.110 & & \\
PCOMP & -0.067 & 0.047 & \\
NPCOMP & 0.125 & 0.110 & 0.065 \\
\hline
\end{tabular}

